\title{
Preliminary Study On Parasites In Loggerhead Turtles (Caretta Caretta) From The Southern Tunisian Waters
}

\author{
Karaa $\mathbf{S}^{* 1}$, Jribi I ${ }^{2}$, Marouani $\mathbf{S}^{1}$ Jrijer J $\mathrm{J}^{2,3}$ and Bradai $\mathbf{M N}^{1}$ \\ ${ }^{1}$ Institut National des Sciences et Technologies de la Mer, Route de Madagascar-3000 Sfax, Tunisia \\ ${ }^{2}$ Faculté des Sciences de Sfax, route de Soukra km 4 B.P n804-3038 Sfax, Tunisia \\ ${ }^{3}$ WWF North Africa, Tunisia \\ *Corresponding author: Sami Karaa, Institut National des Sciences et Technologies de la Mer, Route de Madagascar- 3000 Sfax,Tunisia. \\ To Cite This Article: Sami Karaa. Preliminary Study On Parasites In Loggerhead Turtles (Caretta Caretta) From The Southern Tunisian Waters. Am \\ J Biomed Sci \& Res. 2019 - 5(5). AJBSR.MS.ID.000947. DOI: 10.34297/AJBSR.2019.05.000949.
}

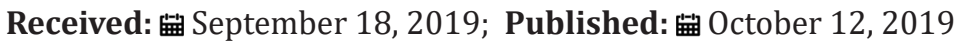

\begin{abstract}
Objective: The occurrence of parasites has been used not only to assess the health status of their hosts, but also as an important tool to understand aspects of the biology of the host, namely their migratory behaviour, distribution and feeding ecology.

Material and Methods: The presence of parasitic agents onthe loggerhead sea turtle in the Gulf of Gabes (South of Tunisia) was performed on five stranded and two accidentally caught animals between 2005 and 2010

Results: Three helminthic species were found in the intestine (one digenean trematode and two nematodes) and two species of ectoparasites (one herpacticoid copepod and one annelid) were recorded in different locations of the body.

Conclusions: The parasitological findings here described are consistent with previous reports from loggerheads in the Mediterranean. Further studies appear necessary to outline the parasitic fauna of the Loggerhead turtles from the gulf of Gabes as an important foraging and wintering area in the Mediterranean Sea.
\end{abstract}

Keywords: Parasites, Loggerhead turtles,Tunisia

\section{Introduction}

In the last decades the occurrence of parasites have been used not only to assess the health status of their hosts, but also as an important tool to understand aspects of the host's biology, namely their migratory behavior, distribution and feeding ecology. Among host, the sea turtles are no exception regarding their parasites infection. Loggerhead turtles (Caretta caretta) the most abundant marine turtles in the Mediterranean Sea harbour a great variety of metazoan parasites belonging to the Trematoda, Nematoda, Cestoda and Hirudinea Class. In this study, we present preliminary information about the parasite fauna of Caretta caretta from the Gulf of Gabes (Southern Tunisian water).

\section{Methods}

As a part of a project evaluating the health status of the loggerhead sea turtle along the Tunisian coasts and under the marine turtle stranding network, a systematic study was performed to assess the presence of infective agents of the loggerhead sea turtle in the Gulf of Gabes (southern Tunisian) (Figure 1). A total of five stranded and two accidentally caught loggerhead (Curved carapace length SCCL, ranging from 47 to $59 \mathrm{~cm}$ ) collected between [1] and 2010 were studied in respect to their metazoan parasites. Parasitological examinations of the stomach and intestine were carried out. The helminths were collected and preserved in $70^{\circ}$ alcohol. The nematodes were clarified in lactophenol and the trematodes were stained with carmine aluminic acetate, before being studied microscopically. Ectoparasites were removed from the external surface of the turtles and then fixed and preserved in $70 \%$ ethanol (Figure 1). 


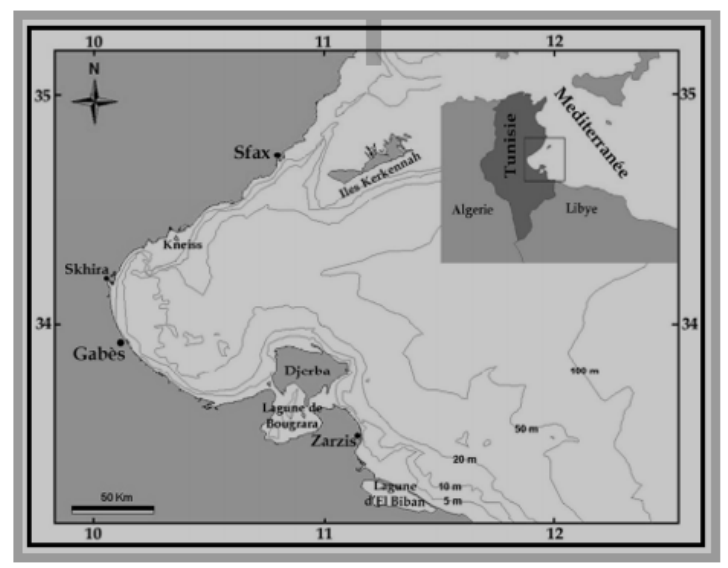

Figure 1: Map of the Gulf of Gabes.

\section{Results}

Three helminths species: one digenean trematode: Diaschistorchis pandus (Braun, 1901) and two nematodes: Kathlania leptura (Rudolphi, 1819) and [2] (Lane, 1914) were located in the intestine of three accidentally caught loggerhead (Table 1). Two ectoparasites species were recorded in different locations. The copepod of the genus Harpacticoida was found on the carapace of a single accidentally caught loggerhead turtle, this copepod seems to be a Balaenophilus sp. Many Hirudinea identified as Ozobranchus margoi (Davies and Chapman 1974) were located mainly between the carapace and the plastron of three sampled turtles (two stranded and one accidentally caught) (Table 1) (Figure 2-5).

\begin{tabular}{|c|c|c|c|c|c|c|}
\hline Parasites & Date & SCCL (cm) & Method & Status & Number & Position \\
\hline \multicolumn{7}{|c|}{ Endoparasites (Figure 2.3) } \\
\hline \multicolumn{7}{|l|}{ Class Trematoda } \\
\hline $\begin{array}{l}\text { Diaschistorchis } \\
\text { pandus }\end{array}$ & 2009: MAR 27 & 53 & Stranded & Fresh dead turtle & 39 & intestine \\
\hline \multicolumn{7}{|l|}{ Class Nematoda } \\
\hline Tonaudia tonaudia & 2005: JAN 10 & 48 & Stranded & Fresh dead turtle & 47 & intestine \\
\hline Kathlania leptura & 2006: SEP 9 & 53 & Stranded & Fresh dead turtle & 8 & Intestine \\
\hline \multicolumn{7}{|c|}{ Ectoparasites (Figure 4.5) } \\
\hline \multicolumn{7}{|l|}{ Class Maxillopoda } \\
\hline Harpacticoida sp & 2005: JAN 30 & 71 & accidentally caught & Fresh dead turtle & & Carapace \\
\hline \multicolumn{7}{|l|}{ Class Hirudiniae } \\
\hline \multirow[t]{3}{*}{$\begin{array}{l}\text { Ozobranchus } \\
\text { margoi }\end{array}$} & 2007: FEB 02 & 59 & Stranded & Putrefy & 97 & $\begin{array}{l}\text { Between the } \\
\text { carapace and the } \\
\text { plastron }\end{array}$ \\
\hline & 2008: MAR 10 & 57,5 & Stranded & Fresh dead turtle & 6 & Around the cloaca \\
\hline & 2010: JAN 04 & 47 & accidentally caught & Alive & 3 & Around the cloaca \\
\hline
\end{tabular}
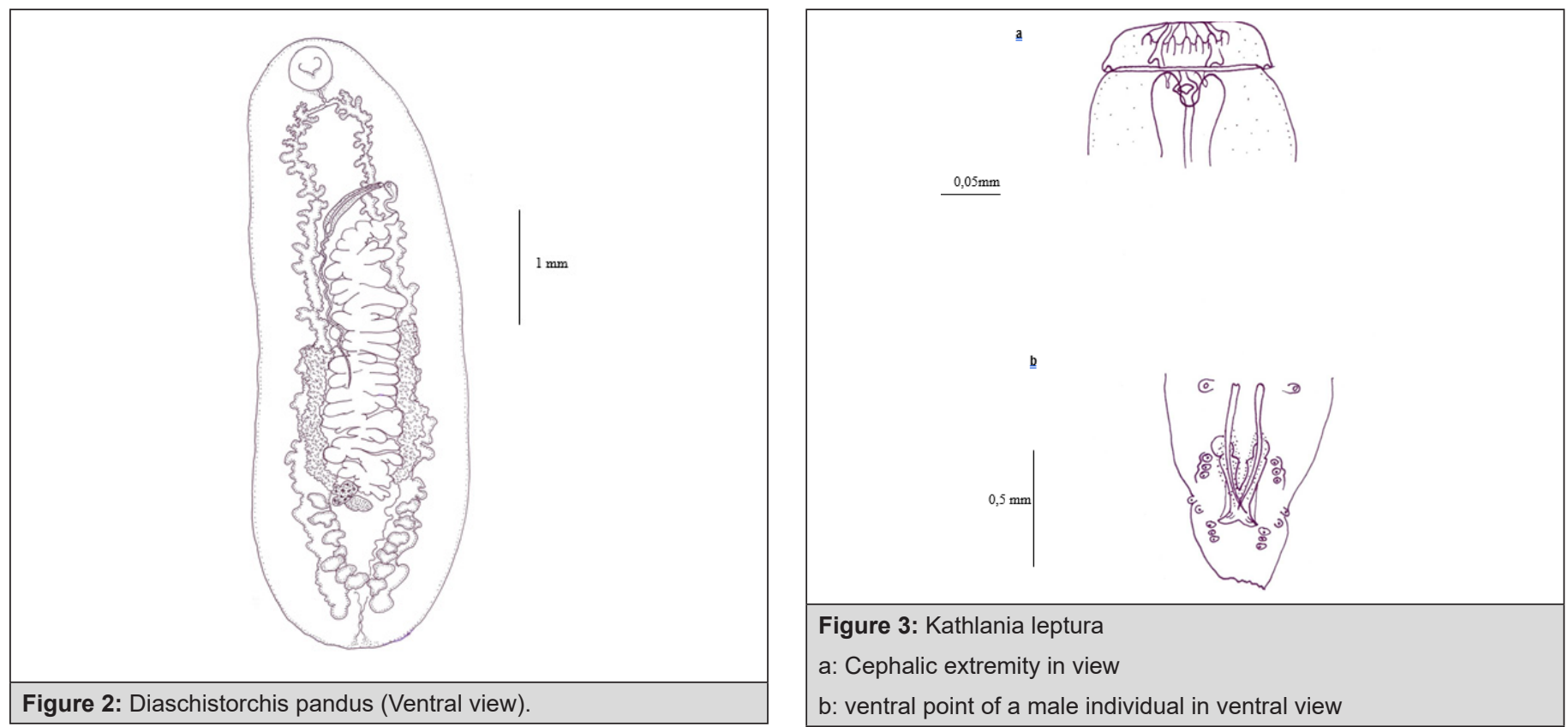

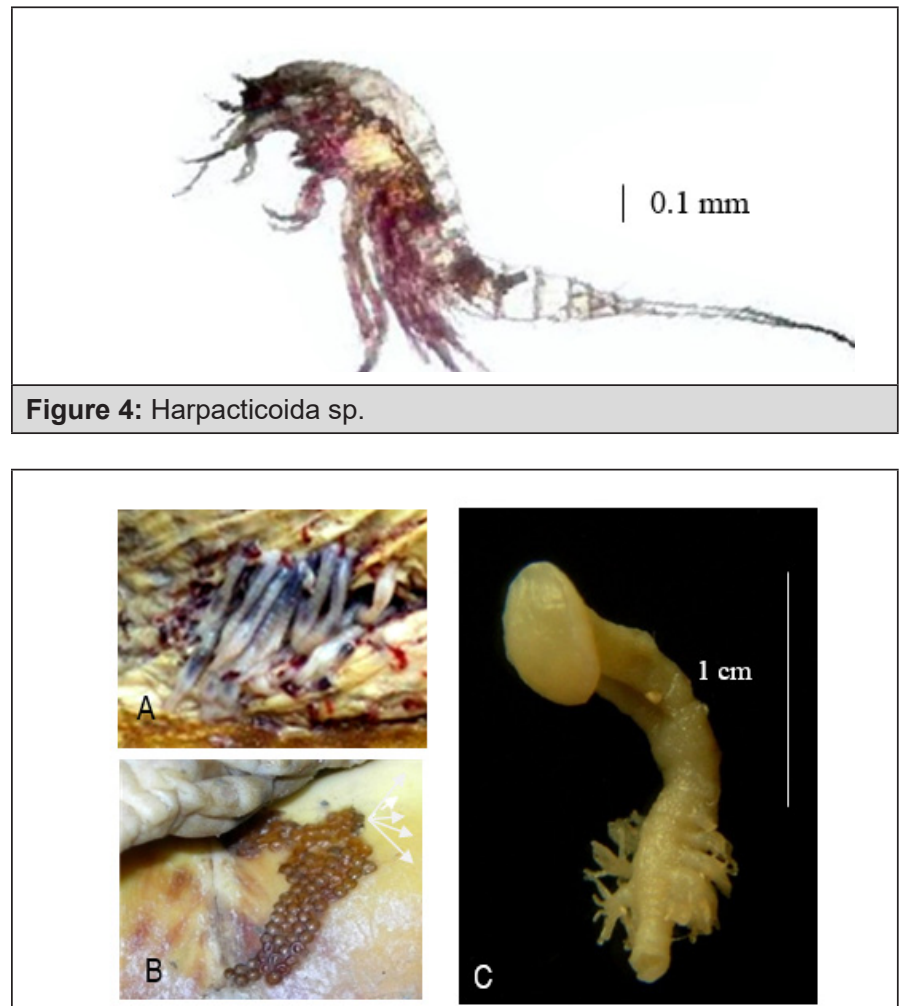

Figure 5: Ozobranchus margoi (Apathy, 1890)

A: O. Margoi

B: Eggs

C: lateral view (- - - gills).

\section{Discussion}

The parasitological findings here described are consistent with previous reports from loggerheads in the Mediterranean (Table 2).
The trematoda Diaschistorchis pandus and the nematoda Tonaudia tonaudia were signaled only in loggerhead from the southern Mediterranean [3] (Gulf of Gabes and Egypt). However, the infrequency of sea turtle's programs In the south Mediterranean Sea, the smallest number of turtles sampled and the difference in sampling period don't allowed us to confirm a clear geographical distribution of these helminthes. Kathlania leptura was present in different Mediterranean area with much higher intensities than those encountered by us (Table 2). Thus, in Egypt, K. leptura was found with a prevalence of $18.3 \%(n=33)$ and an intensity range from 8 to 240 individuals in C. caretta [4]. In Australia [5], found about 200 individuals in one of the turtles examined.

The copepod of the order Harpacticoida was found on the carapace of a single accidentally caught loggerhead turtle. Although it has not proceeded to the identification of this species, there are characters obvious morphological rule out its allocation to the Balaenophilidae family. Given the ecological versatility of the harpacticoid copepods (see [6]) that confirm the regular presence of this species as a commensal of the loggerhead turtle, feeding on diatoms or bacteria that usually grow on the back [7]. Three turtles were found infected with leeches identified as Ozobranchus margoi. This Hirudinea species occurs on most species of Cheloniidae and it is a cosmopolitan ectoparasite of loggerhead turtles. This ectoparasite is most often located on the soft tissues of the body surface. In the Mediterranean Sea, this finding is not common [8]. One stranded loggerhead in February [9] had numerous specimens of Ozobranchus margoi adhered between the carapace and the plastron. Various developmental stages of the parasites were found. A massive infestation of Ozobranchussp can induce pathological effects, like anaemia, because it is a hematophagous parasite [10].

Table 2: Prevalence (\%infected turtles in the sample) of ectoparasites and helminthes of loggerhead Sea turtle Caretta caretta in 5 localities from the Mediterranean Sea

\begin{tabular}{|c|c|c|c|c|c|}
\hline & Locality & & & & \\
\hline Parasites & Egypt [1,2] & Valancia [3,4] & Campania [3] & Adriatic Sea [5] & Agean Sea [6] \\
\hline Diaschistorchis pandus & $(\mathrm{n}=33) 12,1 \%$ & & & & \\
\hline Tonaudia tonaudia & $?$ & & & & \\
\hline Kathlania leptura & $(\mathrm{n}=33) 18,3 \%$ & $(\mathrm{n}=44) 2,3 \%$ & $(\mathrm{n}=32) 15,6 \%$ & $(\mathrm{n}=14) 7,2 \%$ & \\
\hline Harpacticoida sp & & $(\mathrm{n}=30) 78 \%$ & & & \\
\hline Ozobranchus margoi & & $(\mathrm{n}=22) 1,9 \%$ & & $(\mathrm{n}=14) 7,2 \%$ & $(\mathrm{n}=109) 5,4 \%$ \\
\hline
\end{tabular}

\section{Conclusion}

This paper documents, for the first time, the parasites of the loggerhead sea turtle in the southern Tunisian waters. Further studies appear necessary to outline the parasitic fauna of the Loggerhead turtles from the Tunisian waters as they were an important foraging area for loggerheads in the Mediterranean Sea.

\section{Acknowledgements}

Special thanks to Pr. Simonetta MATTIUCCI for its help in the determination of the helminthes samples.

\section{References}

1. Kitsosn MS, Christodoulou M, Arvanitidia C, Mavidis M, Kirmiteoglou I, et al. (2005) Composition of the organismic assemblage associated with Caretta caretta. Journal of the Marine Biological Association of the United Kingdom 85: 257-261.

2. Piccolo G, Manfredi MT (2001) New reports on parasites of marine turtles stranded along the italian coasts. in proceedings of the first mediterranean conference on marine turtles, rome, 24-28 october 2001 (ed. d. margaritoulis and a. demetropoulos) Nicosia: Barcelona ConventionBern ConventionBonn Convention (CMS), Egypt, Pp.207Tonaudia tonaudia 211.

3. Santoro M, Badillo FJ, Mattiucci S, Nascetti G, Bentivegna F, et al. (2010) Helminth communities of loggerhead turtles (Caretta caretta) from 
Central and Western Mediterranean Sea: The importance of host's ontogeny. Parasitol Int 59: 367-375.

4. Sey O (1977) Examination of helminth parasites of marine turtles caught along the Egyptian coast. Acta. Zool. Acad. Sci. Hung. 23: 387-94

5. Lester RJ, Blair D, Heald D (1980) Nematodes from scallops and turtles fromShark Bay, Western Australia. Australian Journal of Marine and Freshwater Research 31(5): 713-717.

6. Hays R, Boxshall GA (1991) Copepod Evolution. The Ray Society, London.

7. Schwartz, FJ (1992) Algal-diatom growths associated with the marine fish sheepshead, Archosargus probatocephalus, and loggerhead, Caretta caretta, and green, Chelonia mydas, sea turtles held in captivity in North Carolina. Bulletin of Marine Science 51(3): 466-474.

8. Meotti C, Bortolotto A, Stanzani LA (1995) Fondazione Cetacea and the conservation of sea turtles. MTN 71: 7-9.

9. Badillo, FJ (2007) Epizoitos y parasitos de la tortuga boba (Caretta caretta) enel Mediterraneo Occidental. Thesis, Universitat de Valencia, Spain.

10. Ernst, E M, Ernst CH (1977) Synopsis of helminthes endoparasitic innative turtles of the United States. Bull Md HerpetolSoc 13(1): 1-75. 